Stocker, B. A. D. \& Campeell, J. C. (1959). J. gen. Microbiol. 20, 670-685

\title{
The Effect of Non-Lethal Deflagellation on Bacterial Motility and Observations on Flagellar Regeneration
}

\author{
By B. A. D. STOCKER AND JANET C. CAMPBELL \\ Guinness-Lister Research Unit, The Lister Institute of Preventive Medicine, \\ Chelsea Bridge Road, London, S.W. 1
}

SUMMARY: The flagellation and motility of Salmonella typhimurium were unaffected by proteolytic enzymes; but when washed stationary-phase bacteria were briefly exposed to acid (e.g. pH 2.6 for 30 sec. at $43^{\circ}$ ) the proportion of motile, and of flagellated, bacteria was decreased from more than $50 \%$ to less than $1 \%$, with little or no decrease in viable count. When S. typhimurium or Vibrio metchnikovi grown on stiff agar were rubbed for several minutes on the agar, the proportion of motile and of flagellated bacteria was decreased from $c .90 \%$ (found in control bacteria, soaked off without rubbing) to $c .1 \%$, without decrease in viable count. High-speed stirring in a blendor also deflagellated and destroyed the motility of $S$. typhimurium in suspension, without killing the bacteria or retarding their growth. Blendor treatment sufficient to deflagellate $S$. typhimurium had no effect on the movements of certain non-flagellated motile organisms (Leptospira canicola, Treponema pallidum and T. duttoni), except when it caused gross morphological changes, attributed to cell damage. When log-phase broth cultures of $\boldsymbol{S}$. typhimurium deflagellated in the blendor were incubated, bacteria with flagella (at first all short) and motile bacteria soon reappeared. At first many bacteria rotated; this suggests that flagella shorter than $c .0 \cdot 3 \mu$ cause rotational, but not translational, motility. The rate of increase of mean summed flagellar length/bacterium was compatible with the hypothesis that flagella are not (spontaneously) shed in broth cultures of $S$. typhimurium and that the rate of growth of flagella is unaffected by deflagellation. Up to one generation time after deflagellation the mean number of flagella/bacterium was, however, less than before deflagellation. It is inferred that in a log-phase culture about half the flagella present at any one moment are 'fully-grown', incapable of being regenerated when broken off. All the results obtained are compatible with the hypothesis that the motility of flagellated bacteria is due to active movement of their flagella.

During work on the genetics of motility and flagellation in salmonella a nonlethal method of removing flagella from bacteria was needed. No satisfactory way of stripping selected individual bacteria of their flagella has been found, but it appeared that whole cultures might be deflagellated, without killing the bacteria, by several different methods. Such methods should provide a test of the hypothesis that the motility of flagellated bacteria results only from the active movement of their flagella, for total removal of the flagella would then necessarily result in loss of motility; whereas if normal motility in salmonella, etc., results from alterations of the shape of the bacterial body (Pijper, 1948, 1957), a treatment which removed all flagella might still leave motility unaffected. The effect of the application of similar treatment to motile bacteria which do not possess flagella (Leptospira, etc.) was also investigated, as a partial 'control' on the effects, other than deflagellation, of one of the treatments used. The manner and rate of the reappearance of flagellar 
in deflagellated salmonella cultures was investigated, both in respect of the correlation of flagellation with motility, and as a means of studying the method by which flagella are produced by bacteria.

\section{METHODS}

Organisms and media. In most experiments strain LT2 of Salmonella typhimurium was used; to obtain highly motile cultures, it was inoculated on to a semi-solid medium and recovered from the advancing edge of the spreading growth produced at $37^{\circ}$. Nutrient broth and agar were prepared from a tryptic digest of beef, or from a papain digest of horse meat. Except where otherwise stated, cultures were incubated statically at $37^{\circ}$.

Examination of flagella. Bacterial suspensions were fixed, washed, mounted, stained and counterstained by the method of Leifson (1951), with the modification of Quadling (1958). In some experiments, the fixed bacteria were washed with distilled water before staining, not by centrifugation as in Leifson's method, but by washing on the surface of a membrane filter. The stained films were examined microscopically; phase-contrast illumination facilitated the detection of non-flagellated bacteria. To determine the proportion of flagellated bacteria and the average no. flagella/bacterium, every bacterium encountered during several scans across a well-stained part of the film was examined and its flagella, if any, were counted. To avoid confusion with non-specific stain granules only filaments of a certain minimum length (generally one eye-piece micrometer unit, i.e. $0 \cdot 72 \mu$ ) were reckoned as flagella. The lengths of individual flagella, i.e. distance in a straight line from tip to point of attachment, were measured with an eye-piece micrometer scale, every flagellum of each of a series of bacteria being measured for the calculation of the average flagellar length; these measurements were necessarily of low precision.

Determination of proportion of motile bacteria. In experiments on salmonella, this was done by low-power dark-ground microscopy of wet preparations, generally in a Helber counting chamber (hanging drops are not suitable for this method of illumination). Bacterial suspensions were usually examined immediately; when this could not be done, they were either stored at $4^{\circ}$ or a bacteriostatic concentration of chloramphenicol was added, since this compound had been found to prevent synthesis of flagella without affecting bacterial motility. It has been found (Stocker, unpublished) that salmonella and other flagellated bacteria when well washed in saline, Ringer's solution or similar salt solutions, lose their motility (though not their flagella), but rapidly regain it when broth, any amino acid, bovine serum albumin, or a high concentration of phosphate are added. To avoid any risk of such 'paralysis', broth was always added to bacteria suspended in inorganic solutions before examination for motility. When a large proportion of the bacteria were motile, every bacterium crossing the central part of the field during a rapid scan was recorded as motile (either in translational movement or rotating) or non-motile; this scoring was difficult, and the results recorded should be regarded only as 
rough approximations. When only a very small proportion of the bacteria were motile the average number of bacteria in a block of counting chamber squares was first determined, and then several such blocks were rapidly searched for motile bacteria.

\section{RESULTS}

\section{Deflagellation by chemical methods}

Since it is known that the flagella of bacteria of several genera consist of protein (Weibull, 1949), pure trypsin, pure chymotrypsin and several crude preparations containing proteolytic enzymes were tested on live and killed Salmonella typhimurium. These agents had no action on the flagella as judged by flagellar staining; bacterial motility was also unaffected. Preliminary denaturation by heat or urea might have increased the susceptibility of the flagella to proteolytic enzymes, but as these treatments might be lethal they were not used.

Weibull \& Tiselius (1945) and Weibull (1948) found that purified flagella from bacteria of several genera rapidly disintegrated at $\mathrm{pH}$ 3-4. Duncan (1935) reported that salmonella suspensions treated with dilute mineral acid were no longer agglutinable by anti-H sera, and that when live bacteria were treated with an amount of acid just sufficient to destroy their $\mathrm{H}$-agglutinability their viability was little affected. These observations suggested that it might be possible to destroy the flagella of live bacteria by short exposure to acid without killing them. Preliminary experiments showed that at $\mathrm{pH}$ values 2.7-3.1 Salmonella typhimurium cultures in the logarithmic phase of growth were killed about four times as fast as stationary-phase cultures. Agar slope cultures incubated overnight at $37^{\circ}$ were therefore used. The bacteria were washed off, and washed once in distilled water on the centrifuge to remove traces of broth which might have had an unwanted buffering action. Meynell (1955) showed that the bactericidal action of citrate + phosphate buffers was the same as that of hydrochloric acid solutions of the same $\mathrm{pH}$ value; citrate + phosphate buffers, of molarity about $1 / 7$, were therefore used. Since the rate of lysis of flagella by acid is temperature-dependent (Weibull \& Tiselius, 1945) the acid treatment was done at $c .44^{\circ}$. Early experiments suggested that exposure to $\mathrm{pH}$ values in the range $2 \cdot 2-3 \cdot 2$ for about $1 \mathrm{~min}$. might destroy the flagella without killing the bacteria. Samples of a dense suspension of washed $S$. typhimurium were therefore added to tubes of buffer solutions of nominal $\mathrm{pH}$ values $2 \cdot 4,2 \cdot 6,2 \cdot 8$ and $3 \cdot 0$. The treatment was terminated after $\frac{1}{2}, 1$ or 2 min. by adding a large volume of neutral phosphate buffer. Viable counts and determinations of the proportion of motile and flagellated bacteria were then made from certain of the treated suspensions, and from a control sample treated in neutral buffer instead of in acid. It will be seen (Table 1) that $\frac{1}{2}$ min. at $\mathrm{pH} 2 \cdot 4$ or $2 \cdot 6$, or 2 min at $\mathrm{pH} 2 \cdot 8$, decreased the proportion of bacteria with flagella detectable by staining from $c .64 \%$ to less than $1 \%$. The viable count was only slightly decreased by these treatments. The proportion of bacteria which showed translational motility was correspondingly depressed to less than $1 \%$, as would be expected if only flagellated salmonella can swim. 
In the $\mathrm{pH} \mathrm{3.0} \mathrm{buffer} \mathrm{deflagellation} \mathrm{was} \mathrm{less} \mathrm{rapid} \mathrm{than} \mathrm{at} \mathrm{lower} \mathrm{pH}$ values and the proportions of motile and flagellated bacteria were 30 and $32 \%$, respectively, after $\frac{1}{2} \mathrm{~min}$. exposure; and 3 and $9 \%$ after $1 \mathrm{~min}$. exposure.

\section{Table 1. Viability, flagellation and motility of stationary-phase Salmonella typhimurium after acid treatment}

The growth on overnight nutrient agar slopes of Salmonella typhimurium strain LT2 was washed off in distilled water; $0.1 \mathrm{ml}$. of dense suspension $\left(\right.$ c. $4 \times 10^{10} / \mathrm{ml}$.) was added to $0.9 \mathrm{ml}$. of acid buffer at $43^{\circ}$. After the indicated time $9 \mathrm{ml}$. of $\mathrm{pH} 7 \cdot 1$ buffer was added. Flagellation determined on formalin-fixed samples, motility and viable counts on samples diluted in broth.

\begin{tabular}{|c|c|c|c|c|c|c|c|}
\hline & & & & & Flagell & ationt & \\
\hline Trea & tment & Viable & Motility* & & & Mean no. & Mean \\
\hline $\begin{array}{c}\mathrm{pH} \\
\text { value }\end{array}$ & $\begin{array}{l}\text { Time } \\
\text { (min.) }\end{array}$ & $\begin{array}{l}\text { (proportion } \\
\text { of control) }\end{array}$ & $\begin{array}{l}\text { of bacteria } \\
\text { motile) }\end{array}$ & $\begin{array}{l}\text { of bacteria } \\
\text { with flagella }\end{array}$ & $\begin{array}{c}\text { flagella/ } \\
\text { bacterium }\end{array}$ & $\begin{array}{l}\text { flagellate } \\
\text { bacterium }\end{array}$ & $\begin{array}{l}\text { length } \\
(\mu)\end{array}$ \\
\hline $2 \cdot 4$ & $\frac{1}{2}$ & $0 \cdot 75$ & $<0.001$ & $<0.01$ & - & - & - \\
\hline & 1 & $0 \cdot 23$ & - & - & 一 & - & - \\
\hline & 2 & 0.011 & - & - & - & - & - \\
\hline $2 \cdot 6$ & $\frac{1}{2}$ & $1 \cdot 0$ & 0.001 & $<0.01$ & - & - & - \\
\hline & if & 0.72 & $<0.001$ & - & - & - & - \\
\hline & 2 & $0 \cdot 26$ & - & - & - & 一 & - \\
\hline $2 \cdot 8$ & 1 & - & $0 \cdot 0005$ & - & - & - & - \\
\hline & 2 & $0 \cdot 65$ & - & $<0.01$ & - & - & - \\
\hline $\mathbf{3} \cdot \mathbf{0}$ & $\frac{1}{2}$ & - & $0 \cdot 3$ & 0.32 & 0.4 & $1 \cdot 3$ & $4 \cdot 3$ \\
\hline & 1 & - & 0.03 & 0.09 & $0 \cdot 13$ & $1 \cdot 5$ & $3 \cdot 4$ \\
\hline & 2 & $0 \cdot 79$ & $0 \cdot 006$ & - & - & - & - \\
\hline $7 \cdot 1$ & $2+$ & $1 \cdot 0$ & - & $0 \cdot 64$ & 0.96 & 1.5 & $6 \cdot 4$ \\
\hline
\end{tabular}

In films made from suspensions which had been incompletely deflagellated (e.g after $1 \mathrm{~min}$. at $\mathrm{pH} \mathrm{3.0)}$ the average number of flagella/flagellated bacterium was about the same as in the control. This suggests that the original bacterial suspension was perhaps heterogeneous in respect of the acid-lability of the flagella of individual bacteria. Similarly, the very small number of motile bacteria found in some preparations were presumably bacteria with unusually acid-resistant flagella. To test whether such bacteria produced progeny with acid-resistant flagella, individual motile bacteria were isolated by micro-manipulation from some of the treated preparations, by the method of preliminary concentration by centrifugation and a 'trapping' drop (Stocker, $1956 b$ ) to facilitate the detection of a very small minority of motile organisms. Cultures grown from two motile organisms isolated from a suspension treated in $\mathrm{pH} \mathrm{2.6}$ buffer for $1 \mathrm{~min}$. were compared with two control cultures grown from single organisms isolated from the control suspension and not treated with acid. All four cultures were washed and given a standard acid treatment; 
the extent to which motility was lost was about the same in all. Thus the minority of bacteria which remained motile after acid treatment were not mutants with acid-tolerant flagella.

\section{Deflagellation by mechanical methods}

Although it is known that flagella may be removed from some bacteria by vigorous shaking or repeated pipetting of dense suspensions neither method was found satisfactory for the present purpose. In particular even prolonged shaking of a Salmonella typhimurium suspension on a mechanical shaker at about 200 strokes/min. had but little effect on the proportion of motile

Table 2. Effects of rubbing on stiff agar on the viability, motility and flagellation of a culture of Salmonella typhimurium

S. typhimurium strain LT2 was grown for c. $18 \mathrm{hr}$. at $30^{\circ}$ on stiff nutrient agar in a large tray. One part of the agar was cut out, and the bacteria washed off; the growth from another part was scraped together and rubbed over the agar for $3 \mathrm{~min}$. and then washed off. The motility, flagellation, viable count and turbidities of the two suspensions were then measured.

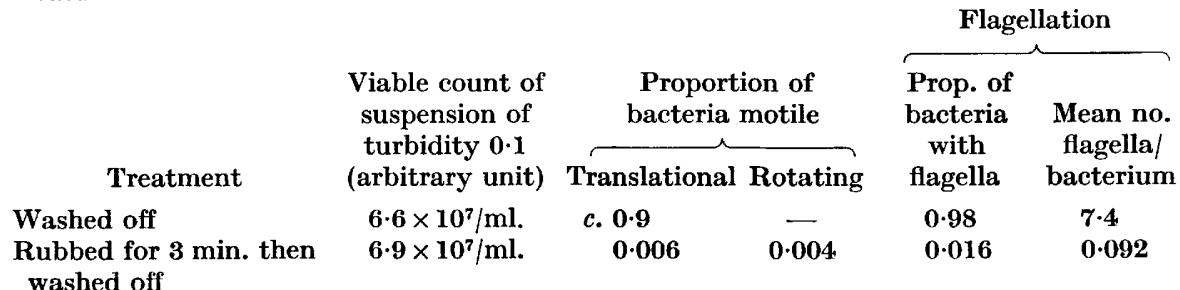

bacteria. However, it was observed that only a small proportion of the bacteria were motile in suspensions of $S$. typhimurium harvested from the surface of nutrient agar plates by scraping off the growth with a glass rod, whereas when the bacteria were washed off the agar a high proportion were motile. This suggested that rubbing the film of bacterial growth over the surface of agar might detach the flagella. Experiments showed that the loss of motility was most complete when rather stiff nutrient agar (e.g. $3 \%(\mathrm{w} / \mathrm{v})$ New Zealand agar) was used, and that after a period of rubbing sufficient to destroy motility very few or no flagellated bacteria were visible in stained films. To see whether the rubbing killed the bacteria, as well as deflagellating them and destroying their motility, bacteria were washed off two different portions of a single tray of stiff nutrient agar, either without rubbing or after several minutes rubbing to and fro over the agar surface with a bent glass rod. The suspensions of rubbed and control bacteria were diluted and their exact turbidities were measured; counts of viable bacteria were then made, and the proportions of motile and of flagellated bacteria were determined on live and stained preparations, respectively. From the results of the experiment (Table 2), it may be inferred that rubbing decreased the proportion both of flagellated and of motile bacteria from $90 \%$ or more to about $1 \%$, without decreasing to a detectable extent the number of viable bacteria/"turbidity unit'. A similar experiment was done on Vibrio metchnikovi, grown on stiff 
nutrient agar at $30^{\circ}$ for $18 \mathrm{hr}$. The suspension of the washed-off organisms contained c. $60 \%$ of motile (translating) and c. $96 \%$ of flagellate bacteria (about half of these having a flagellum at each pole); a suspension of the growth which had been rubbed over the agar for $3 \mathrm{~min}$. contained less than $1 \%$ of bacteria in translational movement and only $5 \%$ of flagellated bacteria, those seen having each one very short flagellum only. The viable count was not significantly decreased.

The few flagellated bacteria which were detected in stained films of the rubbed bacteria (Table 2) included some with several long flagella; these resembled untreated bacteria. These unaffected bacteria were presumably those detected as normally motile in wet preparations. Their retention of flagella probably resulted from accidental escape from rubbing, perhaps in a mass of bacteria on the upper surface of the glass spreader, and not from any exceptional resistance to deflagellation, as in the case of the few motile bacteria in acid-treated suspensions.

Table 3. Effect of blendor treatment of varying duration on the motility, flagellation and viable count of a suspension of Salmonella typhimurium

A log-phase $37^{\circ}$ broth culture of $S$. typhimurium strain LT2 was centrifuged, and the bacteria were suspended in quarter-strength Ringer's solution. $10 \mathrm{ml}$. portions were blended for the indicated times, and immediately examined for viable count and motility, and fixed for staining.

$\begin{array}{cc}\begin{array}{c}\text { Duration of } \\ \text { treatment } \\ \text { (sec.) }\end{array} & \begin{array}{c}\text { Viable } \\ \text { count/ml. }\end{array} \\ 0 & 8.4 \times 10^{7} \\ 15 & - \\ 45 & 11.2 \times 10^{7} \\ 120 & 9.7 \times 10^{7} \\ 360 & 10.7 \times 10^{7}\end{array}$

\begin{tabular}{|c|c|c|}
\hline \multicolumn{2}{|c|}{$\begin{array}{l}\text { Proportion of } \\
\text { bacteria motile }\end{array}$} & \multirow{2}{*}{$\begin{array}{c}\text { Proportion } \\
\text { of bacteria } \\
\text { flagellated* }\end{array}$} \\
\hline Translational & Rotating & \\
\hline $0 \cdot 90$ & - & 0.92 \\
\hline 0.44 & $0 \cdot 36$ & 0.50 \\
\hline 0.09 & 0.51 & $0 \cdot 22$ \\
\hline 0.01 & $0 \cdot 16$ & $0 \cdot 16$ \\
\hline 0 & $0 \cdot 15$ & $0 \cdot 08$ \\
\hline
\end{tabular}

* Only bacteria with one or more flagella of length at least 3 micrometer units $(2 \cdot 1 \mu)$ were scored as flagellated.

Violent stirring of a bacterial suspension by a high-speed propeller in a 'blendor' has been shown to remove the filamentous appendages known as 'fimbriae' from a fimbriate strain of Escherichia coli (Brinton, Buzzell \& Lauffer, 1954) and to detach the head membranes of adsorbed phage particles (Hershey \& Chase, 1952), in each case without destroying the organisms. Experiments showed that treatment of suspensions of Salmonella typhimurium for a few minutes in an M.S.E. blendor (Measuring and Scientific Equipment Ltd., Spenser Street, London, S.W. 1) with the 'universal container' type of bottle (capacity $c .25 \mathrm{ml}$.) resulted in almost complete deflagellation and loss of motility, without detectably lowering the viable count. Table 3 records the results of one experiment. It will be seen that treatment for $45 \mathrm{sec}$. sufficed to decrease the proportion of flagellated bacteria from about 92 to $22 \%$, and of bacteria which showed translational motility from about 90 to $9 \%$; treatment for 120 sec. further decreased these proportions to 16 and $1 \%$; but even treatment for 360 sec. caused no decrease in viable count. 
Similar experiments showed that a period of blending which decreased the proportion of flagellated, and of motile, bacteria in a log-phase broth culture to zero did not retard subsequent growth, as judged by the comparison of viable counts and turbidity with those of untreated portions of the same suspensions.

The proportion of bacteria rendered non-motile by a standard treatment in the blendor varied from experiment to experiment. On some occasions only $1 \%$ or less of the treated bacteria showed any movements detectably greater than Brownian, whereas in other experiments, e.g. that recorded in Table 3, many of the treated bacteria were seen to be spinning, but not progressing. Staining of samples from such preparations showed the presence of many bacteria with very short flagella, presumably stumps left by the breaking-off of the distal part of originally longer flagella. In an attempt to discover the means by which blending removed the flagella, the effect of various factors on the extent of loss of motility was investigated. Portions of a single suspension were blended for $10 \mathrm{sec}$. at concentrations of $5 \times 10^{10}, 5 \times 10^{9}$ and $5 \times 10^{8}$ bacteria/ml.; in all three samples the proportion of motile bacteria was decreased about equally, i.e. from $c$. 80 to 5-10\%. It may be inferred that the loss of flagella did not result from the collision of one bacterium with another, or with the flagella of another. Loss of motility was more nearly complete when the volume blended in a 'universal container' was $10 \mathrm{ml}$. (depth of liquid c. $25 \mathrm{~mm}$.) rather than $20 \mathrm{ml}$., presumably because the shearing motion in the upper part of the suspension, i.e. further from the stirring blades, was less intense. It was also more nearly complete when the bacteria were in suspension in normal saline or in Ringer's solution instead of in broth, probably because in the latter medium bacteria escaped from the shearing field by entrapment in the froth which formed as soon as blending was begun. Blending was more effective at lower temperatures $\left(4^{\circ}\right.$ better than room-temperature, and room-temperature better than $37^{\circ}$ ), presumably because of the greater viscosity of water at lower temperatures. The actual speed of the propeller shaft during blending treatment was found to be about $12,000 \mathrm{rev} . / \mathrm{min}$. and to be about the same for broth or water. A short treatment, insufficient for complete deflagellation, much decreased the average length of the flagella. This suggests that blending removed flagella by repeated breaking-off of the distal parts of the flagella rather than by breaking them off at the base. The persistence of a minority of rotating bacteria, and of bacteria with very short flagella, even after periods of blending several-fold longer than that which sufficed to remove the greater part of the flagella (Table 3) suggests that the probability of a flagellum being broken off during blending is inversely related to its length.

The blending method has been applied to flagellated bacteria of several genera. In an experiment with a strain of Brucella bronchiseptica, blending in broth for $60 \mathrm{sec}$. decreased the proportion of bacteria in translational movement from $c .40$ to $c .0 \cdot 2 \%$ and greatly decreased the proportion of flagellated bacteria without affecting the viable count. It was also observed that blending destroyed the motility of suspensions of a Sarcina, a Pseudomonas and a strain of Spirillum mancuniense, the latter being a free-living spirillum with tufts of 
flagella at one or both poles (Cayton \& Preston, 1955). Viable counting and flagellar staining was not done in these cases.

To test the effect of blending on the $\mathbf{H}$-agglutinability of the bacteria a broth culture of Salmonella typhimurium in phase 2 was divided into two parts, one of which was blended. Both parts were formalinized and tested for agglutinability by an anti-H serum (anti-1, 2, 3). The unblended portion was agglutinated in typical floccules, while the blended sample showed very fine shreds only. One washing of the formalized suspensions did not diminish the agglutinability of the unblended sample; the washed blended suspension showed no detectable agglutination. Presumably, therefore, the agglutinates in the blended suspension consisted of detached flagella, perhaps with some entangled bacterial bodies. These results would be expected if the $\mathrm{H}$-antigen of Salmonella were present only in the flagella, and if the latter were detached by blending. These conclusions are similar to those of Craigie (1931) and correspond to the generally accepted view.

\section{Reappearance of flagellate bacteria in deflagellated suspensions}

When a stationary-phase broth culture of Salmonella typhimurium, deflagellated by blending, was re-incubated without change of medium, only a small proportion of motile bacteria appeared, and these only after a considerable delay. By contrast, when a broth culture in the exponential phase of growth was so treated, the proportion of motile bacteria (at first zero or nearly so) rapidly increased, and after one generation-time was about the same as in non-blended samples of the same culture. The motile organisms which first appeared were nearly all rotating, with little or no translational movement; as incubation continued the proportion of rotating bacteria increased, and then decreased as the proportion in translational movement increased. Staining of samples fixed at times when only rotational motility was obtained showed, as expected, only bacteria with short (or no) flagella. These results, together with those described above on the rotating movement of bacteria in incompletely deflagellated suspensions, suggest that a flagellum shorter than some critical length can rotate, but not propel, the bacterium to which it is attached. The data suggest that this critical length is about $2.9 \mu$. For instance, in one experiment at $36^{\circ}$ at $18 \mathrm{~min}$. after the end of blending the majority of the bacteria were rotating and a few were translating; in a stained film 14 of 20 bacteria scored had at least one flagellum four micrometer units $(=\mathbf{2} \cdot 9 \mu)$ long, but only 6 of these 14 had any flagella five units or more in length.

The increase in average flagellar length on continued incubation of deflagellated bacteria suggested that the Salmonella flagella increased gradually in length, presumably as a result of the gradual secretion and extrusion of flagellum by the bacterium, perhaps through the activity of some sort of basal granule. It is clear that they are not extruded instantaneously, already formed and of fixed length. Different types of experiment (Stocker, 1956 $a, b$; Quadling \& Stocker, 1956 and unpublished; Quadling, 1958) indicated that in broth cultures the flagella of Salmonella were not shed (or were shed only very infrequently) but were retained and continued to function for several or many 
generations. This conclusion and the assumption that deflagellation of a bacterium does not alter the rate at which it produces flagella permit a calculation of the theoretical rate at which the average 'amount of flagellum' (i.e. summed lengths of all flagella)/bacterium will increase from zero towards its original value in a log-phase broth culture incubated after complete deflagellation. The value before deflagellation, i.e. the 'steady-state' value during exponential growth, may be taken as 1, in arbitrary units. At a time $t$ generation-times after deflagellation the proportion of the total bacterial mass which has been produced since deflagellation will be $\left(2^{t}-1\right) / 2^{t}=1-t^{-2}$. The only flagella at this time will be those formed pari-passu with the increase in bacterial mass since deflagellation, and the average flagellar amount/bacterium will therefore also be $\left(1-t^{-2}\right)$ of its value before deflagellation (1, in arbitrary units). This expression (plotted in Fig. 1) has value 0 when $t=0$, and tends to 1 as $t$ increases, i.e. as the effect of deflagellation is extinguished by subsequent growth. To test this prediction broth cultures of Salmonella typhimurium in the logarithmic phase of growth, at $25^{\circ}$ or $37^{\circ}$, were used. A portion of the culture was treated in the blendor, and the treated and control portions of the culture were kept in logarithmic growth by dilution at intervals. Growth was followed by measurement of turbidity, or by viable counts. Samples were taken at intervals for flagellar staining, and the average no. flagella/bacterium and average length/flagellum were measured; their product gave the value of average flagellar amount/bacterium. Three experiments, the results of one of which are recorded in Fig. 1 and Table 4, gave similar results in that the values

Table 4. Reappearance of flagellation after blending in a log-phase $\left(\mathbf{2 5}^{\circ}\right)$ broth culture of Salmonella typhimurium

Part of a broth culture in log. phase of Salmonella typhimurium strain LT2 at $25^{\circ}$ was blended for $5 \mathrm{~min}$., the proportion of motile bacteria being thereby decreased from $c .0 .8$ to less than 0.01. At intervals samples were taken from the blended and unblended portions for staining and measurement of turbidity.

\begin{tabular}{|c|c|c|c|}
\hline Sample & $\begin{array}{c}\text { Average no. } \\
\text { flagella / } \\
\text { bacterium }\end{array}$ & $\begin{array}{c}\text { Average } \\
\text { flagellar } \\
\text { length } \\
(\mu)\end{array}$ & $\begin{array}{c}\text { Average } \\
\text { flagellar } \\
\text { amount/ } \\
\text { bacterium } \\
(\mu)\end{array}$ \\
\hline Unblended, 0 min. & 4.5 & $\mathbf{3} \cdot \mathbf{7}$ & $16 \cdot 8$ \\
\hline 0 min. after blending & $\mathbf{0}$ & - & 0 \\
\hline 20 min. after blending & $2 \cdot 6$ & $1 \cdot 7$ & 4.5 \\
\hline $40 \mathrm{~min}$. after blending & $3 \cdot 8$ & $\mathbf{1 . 9}$ & $7 \cdot 1$ \\
\hline 60 min. after blending & $\mathbf{3} \cdot 7$ & $2 \cdot 4$ & $8 \cdot 9$ \\
\hline 80 min. after blending & 4.5 & $\mathbf{2 \cdot 5}$ & $11 \cdot 2$ \\
\hline $100 \mathrm{~min}$. after blending & 4.2 & $2 \cdot 7$ & $11 \cdot 4$ \\
\hline Unblended, $100 \mathrm{~min}$. & $5 \cdot 4$ & $3 \cdot 7$ & $19 \cdot 8$ \\
\hline
\end{tabular}

of average flagellar amount/bacterium at various times after deflagellation were in reasonable agreement with the predicted curve. Thus, these results, though only of low precision, lend some support to the assumptions made above, viz. that flagella are not shed and that their rate of formation is unaffected by deflagellation. 
If in a log-phase culture every flagellum increased in length at a constant (linear) rate as a result of continuous secretion, all flagella broken off by blendor treatment should re-appear on subsequent incubation; and the average no. flagella/bacterium should remain constant, the average length increasing from zero towards its initial value as incubation continued. However, in all experiments the average no. flagella/bacterium in samples taken less than one

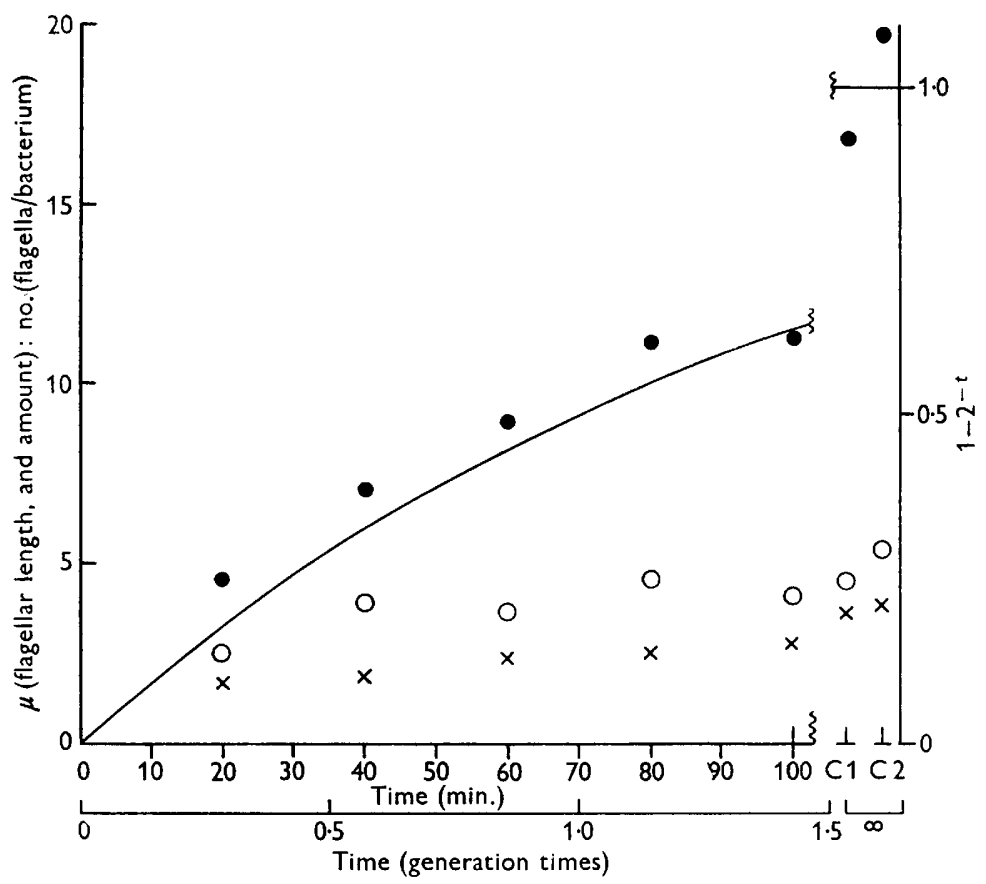

Fig. 1. Reappearance of flagellation after blendor treatment in a log-phase $\left(25^{\circ}\right)$ broth culture of Salmonella typhimurium. $\mathrm{O}=$ mean no. flagella/bacterium; $\times=$ mean length $(\mu)$ /flagellum; $\boldsymbol{\bullet}=$ mean flagellar amount/bacterium. $\mathbf{C 1}=$ observations on untreated portion of culture at time of treatment. C2 $=$ observations on untreated portion at $100 \mathrm{~min}$. Curve represents theoretical return of flagellar amount towards $18.3 \mu$ (mean of $\mathrm{C} 1$ and $\mathrm{C} 2$ values) predicted by values of $1-2^{-t}$, where $t$ is time (in generation-times) since treatment. Generation time, estimated from turbidity measurements, was $70 \mathrm{~min}$.

generation-time after deflagellation was less than in the untreated controls. This deficit in average no. flagella/bacterium during the early stages of regeneration can be explained by the assumption that a flagellum, though it persists (and functions) for many generations, increases in length for only a limited period after its inception. If this be the case, some of the flagella in a culture at any moment will be growing (and will re-appear as short flagella soon after blending) and others will be fully grown flagella formed in earlier generations which once broken-off will not re-grow. The data suggest that rather more than half the flagella present in the cultures tested were not regenerated after blending. As most bacteria showed at least some flagella soon after blending, such non-regenerable flagella were not all carried by a fraction of 
the population with 'old' cell-walls. If this argument be correct, the average flagellar length in samples taken soon after deflagellation will be somewhat less than the product of the time since blending and the average rate of elongation of a flagellum during its phase of growth. In two experiments at $c .37^{\circ}$ the average flagellar lengths at $9 \mathrm{~min}$. (c. $\frac{1}{3}$ of a generation-time) were $1.1 \mu$ and $1.3 \mu$, and in one experiment at $25^{\circ}$ the average length at $20 \mathrm{~min}$. (also $c$. $\frac{1}{3}$ of a generation-time) was $1.7 \mu$. These figures give rates of flagellar elongation of 0.12 and $0.14 \mu / \mathrm{min}$. at $37^{\circ}$, and $0.085 \mu / \mathrm{min}$. at $25^{\circ}$.

The correlation between flagellation and motility found in certain bacterial genera might indicate that flagella are a result of bacterial motility, rather than its cause (Pijper, 1946, 1957). We therefore compared the behaviour after blendor treatment of a non-motile flagellated ('paralysed') strain of Salmonella typhimurium, strain SW 578 (Stocker, Zinder \& Lederberg, 1953; Beighton, Porter \& Stocker, 1958) with that of a motile mutant strain (SL 272) obtained from it by selection in semi-solid medium. Both strains grew at the same rate (generation-time about $26 \mathrm{~min}$. in broth at $35^{\circ}$ ), and both showed about the same degree of flagellar development. No bacterial movement other than Brownian was detected in the 'paralysed' strain, either before or at any stage after blending. Blending removed the flagella almost completely in both strains, and no difference was detected in the rate or manner in which flagellated bacteria re-appeared in the two strains.

\section{Effect of blendor treatment on motile bacteria of non-flagellated genera}

According to electron-micrograph evidence (e.g. Bradfield \& Cater, 1952; Swain, 1955) Leptospira and spirochaetes of the relapsing fever and Treponema pallidum groups lack flagella of the ordinary kind, though the fibrils which are seen when the organisms are broken up bear some resemblance to flagella and perhaps constitute intracellular locomotor apparatus. It was therefore of interest to see whether treatment which sufficed to deflagellate salmonella and other flagellated bacteria would affect the characteristic movements of such non-flagellated organisms. Only blendor treatment was investigated. Because of shortage of material the $5 \mathrm{ml}$. blendor container was used in these experiments; special suspending media were needed to maintain the motility of the spirochaetes. Because of these differences of technique, and because it was found that prolonged treatment caused gross damage to some spirochaetes, a portion of a log-phase broth culture of motile Salmonella typhimurium was added to each suspension before treatment in the blendor, as a control on the efficacy of the treatment. Blood from a mouse inoculated 3 days earlier with a strain of Treponema duttoni was diluted in normal rat serum (to preserve the motility of the spirochaetes) and centrifuged for $5 \mathrm{~min}$.; the supernatant fluid, containing a high concentration of motile spirochaetes, with motile $S$. typhimurium added, was blended for 2 min. The proportion of motile salmonella was decreased from 91 to $9 \%$, and of motile treponemata from 96 to $43 \%$. However, when thin films of the control and blended suspensions were examined by high-power phase-contrast microscopy, it was seen that many of the treponemata had been injured by the blending. In the controls more than 
$90 \%$ of treponemata appeared as regular helical filaments, whereas in the treated sample about half, including nearly all the non-motile ones, were abnormal in shape, appearing either as helical filaments with one or several rounded protrusions, or as irregular filaments, some showing protrusions. Thus, the motility of a spirochaete of the relapsing-fever type was less readily destroyed by blending than that of salmonella; and such loss of motility as occurred probably resulted from damage to the cell-wall which caused death.

A preliminary experiment with a culture of Leptospira canicola showed that blending for $1 \mathrm{~min}$. had no effect on the motility of a suspension of these organisms in Ringer's solution; and that blending for $6 \mathrm{~min}$. had a slight effect, the proportion of non-motile leptospira (neither 'rotating' about their long axis, nor translating) being increased from less than 5 to $c .30 \%$. Many of the non-motile forms seen appeared to be broken. When a mixture of Leptospira and salmonella was blended, treatment for 2 min. decreased the proportion of motile salmonella from 80 to $c .4 \%$, without noticeable effect on the motility of Leptospira. A suspension of Treponema pallidum from a rabbit lesion, prepared for use in the treponema immobilization test, was blended after addition of motile salmonella, the mixture being gassed with $95 \%(\mathrm{v} / \mathrm{v})$ $\mathrm{N}_{2}+5 \%(\mathrm{v} / \mathrm{v}) \mathrm{CO}_{2}$ before and after blending. Treatment for $2 \mathrm{~min}$. decreased the proportion of motile salmonella from $c .66$ to $c .0 \%$, but had no effect on the spirochaetes, $c .80 \%$ of which continued to show the typical non-translational movements of this organism (Sequeira, 1956). It appeared from these experiments that a blending treatment sufficient to destroy the motility of Salmonella typhimurium by deflagellation had little or no effect on the motility of these three types of spirochaete, except when it broke them.

\section{DISCUSSION}

Mechanism of deflagellation. Weibull \& Tiselius (1945) found that purified flagella of Salmonella paratyphi $\mathbf{B}$ were very rapidly destroyed by exposure to acid. Our results confirm their further observation that the flagella of live salmonella are equally acid-sensitive. The finding of a very small proportion of normally motile bacteria in suspensions which had received an acid treatment sufficient to destroy all the flagella of the large majority of bacteria was surprising. It seems unlikely that these were bacteria which had escaped contact with the acid, for the bacterial suspension was blown into the buffer solution, and the tube was shaken to ensure good mixing. Weibull \& Tiselius (1945) made a somewhat analogous observation: after exposure for $20 \mathrm{~min}$. at $\mathrm{pH} \mathrm{3.0}$ and $20^{\circ}$ (at which temperature the destruction of flagella was much slower than at $38^{\circ}$ ) $c .10 \%$ of the flagella in a purified preparation were still visible in the electron-microscope, and these persisters were still present even after exposure for $60 \mathrm{~min}$. The temperatures used in our experiments were intended to avoid this heterogeneous behaviour, but it is possible that a lesser degree of such heterogeneity accounts for our results.

The method of rubbing bacteria grown on agar over the surface has not, we 
think, been previously used for deflagellation. Nicolle (1941, 1943), however, noted that various phages were inactivated by the prolonged rubbing (instead of brief spreading) of suspensions on agar, inactivation being more rapid when a mixture of bacteria and phage was rubbed than when phage alone was rubbed. As to the mechanism of deflagellation by rubbing, it seems a priori that bacteria growing on the surface of agar, that is in a film in which any intercellular spaces must be filled with liquid, will be close-packed, each bacterium being in direct contact with its neighbours. When a mass of closepacked bacteria are sheared by rubbing, it seems likely that a flagellum may be caught between two bacterial bodies and so pulled until it breaks. The ease with which bacteria are deflagellated in this way probably accounts for the common statement that bacterial flagella are "very fragile and easily brokenoff'. Our experiments and those described in the literature do not suggest that this could be said of the flagella of bacteria in suspension.

Several authors have reported that flagella may be detached from bacteria by vigorous and prolonged shaking of bacterial suspensions (e.g. de Rossi, 1904, 1905; Craigie, 1931; Gard, 1944), and in some cases it was shown that bacteria after such treatment had lost all or nearly all their flagella. We failed to deflagellate suspensions of Salmonella typhimurium by shaking, possibly because the machine used was not sufficiently vigorous. Other authors (Leifson, 1930; Mallett, Koffler \& Rinker, 1951) have reported a similar failure. Craigie (1931) stated that even with his specially designed shaker it was possible to deflagellate only when the bacterial suspension was very dense. This suggests that collisions of bacterium with bacterium (or flagellum) are the means by which shaking deflagellates.

High-speed stirring in a blendor was found the most convenient non-lethal method of deflagellation. The way in which the flagella are removed is not clear, except that the equal efficacy of treatment of suspensions of different concentrations establishes that bacterial collisions are not involved, at least when the bacterial concentation is not greater than $5 \times 10^{10}$ organisms $/ \mathrm{ml}$. It seems possible that cavitation is involved. The increased deflagellating effect of treatment at low temperatures, and some incomplete observations which suggest a similar increased efficacy in methyl cellulose solutions, suggest that mere exposure of a flagellated bacterium to a rapid shearing motion in fluid may break off its flagella.

Flagella and bacterial motility. All the experimental data recorded here are compatible with the hypothesis that the motility of Salmonella typhimurium and other flagellated bacteria tested results only from the active movement of their flagella, for deflagellation by any of three different methods resulted in loss of motility without loss of viability. Furthermore, when deflagellation was incomplete, and during the recovery of flagellation and motility after blending, the proportions of motile and of flagellated bacteria were approximately equal. By contrast, blending sufficient to deflagellate $S$. typhimurium had little or no effect on the movements of Treponema pallidum, $T$. duttoni and Leptospira canicola, organisms which lack typical 'extracellular' flagella. These results do not prove that flagella are the locomotor organs of Salmo- 
nella; but on the alternative hypothesis (that motility results from alterations of shape of the bacterial body) they can only be accounted for by the assumption that the non-lethal treatment which removed flagella from bacteria of flagellated species also adversely affected their ability to swim by alteration of body shape, even though it did not affect this ability in the tested species of non-flagellated bacteria. It might be argued that various treatments caused both deflagellation and loss of motility because flagella resulted from bacterial movements, instead of being their cause (cf. Pijper, 1946, 1957); the loss of flagella caused by blending of bacteria of the non-motile flagellated $S$. typhimurium, strain SW 578, and the subsequent reappearance of flagellated bacteria, cannot easily be reconciled with this view. We may refer here to some earlier observations on this problem. It was reported by de Rossi (1904, 1905) that prolonged vigorous shaking of a dense suspension of a Bacillus sp., or of the typhoid bacillus, resulted in loss of motility and in the detachment of the flagella from the bodies. Our experiments are consistent with this. Pijper $(1949,1957)$ reported that $S$. typhi after shaking for $15 \mathrm{~min}$. no longer showed 'tails' when examined by sunlight dark-ground microscopy, though their motility was unimpaired, and cited this as evidence that amputation of flagella does not affect motility. Mallett, Koffler \& Rinker (1951) reported that shaking more vigorous than that used by Pijper did not affect complete deflagellation of $S$. typhi, and it seems probable that the disappearance of 'tails' which he observed resulted either from a decrease in number or length of flagella, or from their diminished aggregation, but not from complete deflagellation.

It was observed in the present work that salmonella with only flagellar stumps (left by incomplete deflagellation) or with the short flagella which first appeared on incubation after complete deflagellation, actively rotated, but showed little or no translational movement. The minimum length of flagellum needed for translational movement was estimated as $c .3 \mu$. If the active movement of a flagellum consists in the continuous propagation of a circular (helical) wave from base to tip, then a certain minimum length may be needed for the generation of the axial thrust which such movement produces, when there is resistance to the torque also produced (Hancock, 1953). In the case of a two-dimensional wave motion a length of at least one wavelength is needed for longitudinal movement (Gray, 1953). The wavelength of the flagella of Salmonella typhimurium, strain LT2, was found to be about $2 \cdot 0 \mu$.

Growth of flagella. The gradual increase in mean flagellar length observed when deflagellated salmonella were incubated indicates that the flagella of this organism grow gradually, and are not produced by the sudden extrusion of a fully formed flagellum. Analysis of the data on mean no. flagella/bacterium and of mean flagellar length in such experiments suggests, as shown above, that a flagellum increases in length for only a limited period after its inception, about half the flagella present at any one time being 'fully grown' and incapable of regeneration when broken off by trauma. Pedigree experiments have, however, shown that motility can be transmitted unilinearly, i.e. down one line of descent, for 20 or more generations (Stocker, 1956 $a, b$; Lederberg, 1956), and there is evidence that this results from persistence of a single 
flagellum (Quadling, 1958). It therefore appears that a flagellum gradually elongates for a limited period (probably between 1 and 2 generation-times), and thereafter persists, and continues to function, for several or many generations, without further elongation. The notion that bacterial flagella grow in length for a limited period only provides a possible explanation for several unpublished observations made in this laboratory. Dr D. Kerridge (personal communication) has found that when bacteria grown in broth are deflagellated and then incubated in a defined medium flagella reappear, but that the average no. flagella/bacterium is always less than before deflagellation, as would be expected if a proportion of the original flagella were 'fullygrown'. Dr C. Quadling (personal communication) has transferred actively growing bacteria from an environment in which flagella developed normally to one in which formation of new flagella ceased, though bacterial growth continued. When such cultures were deflagellated soon after transfer to the new environment some motile bacteria appeared on further incubation, i.e. at least some flagella were regenerated; but when the bacteria were deflagellated after a longer period in the new environment there was no, or very little, regain of motility, presumably because all the flagella initiated before formation of new flagella ceased were 'fully grown' by the time the flagella were removed by blendor treatment. It has also been noted (Stocker \& Quadling, unpublished) that in salmonella the mean no. flagella/bacterium may be varied over a wide range by alteration of genotype or of environment but that the length distribution of the flagella is not obviously altered by such changes. It seems that the 'basal granule' presumed to secrete the flagellum has some degree of autonomy, and that once formed it secretes flagellum for a limited time, even though the conditions are such that no new basal granules are initiated. Dr D. Kerridge (personal communication) has indeed shown that under some conditions bacteria can secrete flagella even though they are unable to grow.

We wish to thank Madame $H$. de Margerie for carrying out the micromanipulation experiment; and Dr P. J. L. Sequeira and Dr B. W. Lacey for supplying spirochaetes.

\section{REFERENCES}

Beighton, E., Porter, A. M. \& Stocker, B. A. D. (1958). X-ray and related studies of the flagella of non-motile bacteria. Biochim. biophys. Acta, 29, 8.

Bradfield, J. R. G. \& CATER, D. B. (1952). Electron-microscopic evidence on the structure of spirochaetes. Nature, Lond. 169, 944.

Brinton, C. C., Buzzell, A. \& Lauffer, M. A. (1954). Electrophoresis and phage susceptibility studies on a filament-producing variant of the $E$. coli $\mathrm{B}$ bacterium. Biochim. biophys. Acta, 15, 533.

Cayton, H. R. \& Preston, N. W. (1955). Spirillum mancuniense n.sp. J. gen. Microbiol. 12, 519.

Craigie, J. (1931). Studies on the serological reactions of the flagella of B. typhosus. J. Immunol. $21,417$.

DE Rossi, G. (1904). Sui fenomeni di agglutinazione dei batteri. Arch. Sci. Med. $28,1$.

DE Rossi, G. (1905). Sui fenomeni di agglutinazione dei batteri. Arch. Sci. Med. 29,455 . 
Duncan, J. T. (1935). Inactivation of the ' $H$ ' antigen by dilute mineral acid. Brit. J. exp. Path. 16, 405.

Gard, S. (1944). Preparation of bacterial flagella. Ark. Kemi Min. Geol. 19 A, no. 21.

Gray, J. (1953). Undulatory propulsion. Quart. J. micr. Sci. 94, 551.

HANCOCK, G. J. (1953). The self-propulsion of microscopic organisms through liquid. Proc. Roy. Soc. A, 217, 96.

Hershey, A. D. \& Chase, M. (1952). Independent function of viral protein and nucleic acid in growth of bacteriophage. J. gen. Physiol. 36, 39.

LEDERBERG, J. (1956). Linear inheritance in transductional clones. Genetics, 41, 845.

Leifson, E. (1930). A method of staining bacterial flagella and capsules together with a study of the origin of flagella. J. Bact. 20, 203.

LeIfson, E. (1951). Staining, shape and arrangement of bacterial flagella. J. Bact. $62,377$.

Mallet, G. E., Koffler, H. \& Rinker, J. N. (1951). The effect of shaking on bacterial flagella and motility. J. Bact. 61, 703.

MeYnel., G. G. (1955). Some factors affecting the resistance of mice to oral infections by Salm. typhimurium. Proc. Roy. Soc. Med. 48, 916.

Nicolle, P. (1941). Diminution du nombre des plages bacteriophagiques sur gélose en fonction du temps d'étalement. C.R. Soc. Biol., Paris, 135, 709.

Nicolle, P. (1943). Appréciation de la taille des corpuscules bactériophages par leur sensibilité au frottement. Ann. Inst. Pasteur, 69, 116.

PiJper, A. (1946). Shape and motility of bacteria. J. Path. Bact. 58, 525.

PiJPer, A. (1948). Bacterial flagella and motility. Nature, Lond. 161, 200.

PiJper, A. (1949). Evidence that amputation of bacterial flagella does not affect motility. Science, 109, 379.

PiJper, A. (1957). Bacterial flagella and motility. Ergebn. ImmunForsch. 30, 37.

QuAdLING, C. (1958). The unilinear transmission of motility and its material basis in Salmonella. J. gen. Microbiol. 18, 227.

Quadlivg, C. \& Stocker, B. A. D. (1956). An environmentally induced transition from the flagellated to the non-flagellated state in Salmonella: the fate of parental flagella at cell division. J. gen. Microbiol. 15, i.

Sequeira, P. J. L. (1956). The morphology of Treponema pallidum. Lancet, ii, 749.

Stocker, B. A. D. (1956a). Bacterial flagella: morphology, constitution and inheritance. In Bacterial Anatomy. Symp. Soc. gen. Microbiol. 6, 19.

STocker, B. A. D. (1956b). Abortive transduction of motility; a non-replicated gene transmitted through many generations to a single descendant. J. gen. Microbiol. 15, 575.

STOCKER, B. A. D., Zinder, N. D. \& LedERBERG, J. (1953). Transduction of flagellar characters in Salmonella. J. gen. Microbiol. 9, 410.

SwaIn, R. H. A. (1955). Electron microscopic studies of the morphology of pathogenic spirochaetes. J. Path. Bact. 69, 117.

Weibull, C. (1948). Some chemical and physico-chemical properties of the flagella of Proteus vulgaris. Biochim. biophys. Acta, 2, 351.

Werbull, C. (1949). Chemical and physico-chemical properties of the flagella of Proteus vulgaris and Bacillus subtilis. A comparison. Biochim. biophys. Acta, $3,378$.

Weibuld, C. \& Tiselius, A. (1945). Note on the acid hydrolysis of bacterial flagella. Ark. Kemi Min. Geol. $20 \mathrm{~B}$, no. 3.

(Received 5 December 1958) 